\title{
Imported cutaneous larva migrans by a 31-year-old French woman after a travel in Gabon
}

\author{
Romain Bricca, ${ }^{1}$ Christian Chidiac, ${ }^{1,2,3}$ Tristan Ferry ${ }^{1,2,3}$
}

${ }^{1}$ Service de Maladies Infectieuses et Tropicales, Hôpital de la Croix-Rousse, Hospices Civils de Lyon, Lyon, France

${ }^{2}$ Université Claude Bernard Lyon 1, Lyon, France

${ }^{3}$ Centre International de Recherche en Infectiologie, CIRI, Inserm U1111, CNRS UMR5308, ENS de Lyon, UCBL1, Lyon, France

\section{Correspondence to} Dr Tristan Ferry, tristan.ferry@univ-lyon1.fr

Accepted 27 July 2016
To cite: Bricca R, Chidiac $C$, Ferry T. BMJ Case Rep Published online: [please include Day Month Year] doi:10.1136/bcr-2016216578

\section{DESCRIPTION}

A 31-year-old French woman presented with typical cutaneous larva migrans following a 1-week visit to Gabon. Five days after her return to France, a serpiginous skin rash appeared on the anteromedial side of the left thigh (figure 1A). It had progressed for 1 week before consultation, and a contralateral lesion also appeared (figure 1B). Both lesions were itchy. The patient did not report other symptoms, such as asthenia, abdominal pain or intestinal disorder. Clinical examination did not reveal any other abnormalities. Biologically, there was no anaemia, hypereosinophila or liver disorder. Serology was negative for strongyloidiasis and toxocariasis. Single dose $12 \mathrm{mg}$ ivermectin associated with an antihistamine was prescribed. On consultation at 1 month, the cutaneous lesions had totally resolved, without recurrence.

Dog or cat hookworm is the most common cause of cutaneous larva migrans in humans. Endemic in tropical and subtropical countries, including South East Asia, the parasites (Ancylostoma caninum, Ancylostoma braziliense or Uncinaria stenocephala) use canids and felids as natural hosts, growing in the animal's intestine before being excreted into the external environment. Human infection occurs after skin contact with larvae, especially during walking or lying on contaminated beaches. The larvae enter into the dermis or epidermis and migrate subcutaneously. During migration, an itchy erythematous cord develops under the skin,

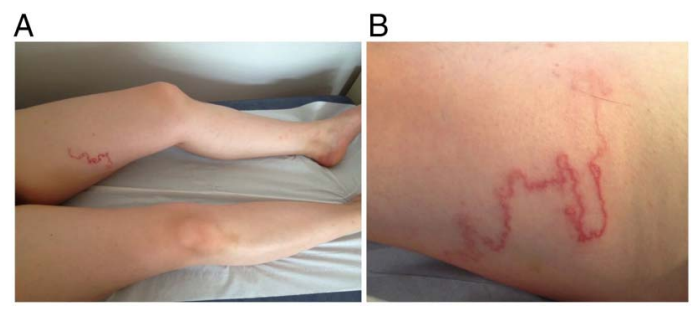

Figure 1 (A) Typical serpiginous erythema of cutaneous larva migrans of the anteromedial side of the left thigh. (B) Identical lesion that occurred a few days later on the anteromedial side of the right thigh. moving $2-3 \mathrm{~cm} /$ day. Since these animal larvae cannot penetrate the basal membrane of human skin, cutaneous larva migrans is a self-limiting disease, as the larvae remain confined to the epidermis (parasitic impasse). ${ }^{1}$ Pruritus intensity and symptom duration are variable. The natural history of cutaneous larva migrans is spontaneous resolution without treatment within a few weeks, but most patients referred to the infectious diseases unit receive antiparasite therapy such as albendazole or ivermectin. ${ }^{2}$ Ivermectin is the drug of choice, with a single dose of $200 \mu \mathrm{g}$ per bodyweight. If the treatment fails, a second dose usually provides definitive cure. ${ }^{12}$

\section{Learning points}

- Cutaneous larva migrans is a common reason for medical consultation after travel in the tropics.

- Dog or cat hookworm is the most common cause of cutaneous larva migrans in humans; larvae enter the epidermis, migrate subcutaneously and remain confined in the epidermis (parasitic impasse).

- Single-dose ivermectin is the treatment of choice for cutaneous larva migrans.

Contributors TF participated in patient care. RB, CC and TF participated in literature review, and writing and revision of the manuscript.

Competing interests None declared.

Patient consent Obtained.

Provenance and peer review Not commissioned; externally peer reviewed.

\section{REFERENCES}

1 Feldmeier H, Schuster A. Mini review: hookworm-related cutaneous larva migrans. Eur J Clin Microbiol Infect Dis 2012;31:915-18.

2 Kincaid L, Klowak M, Klowak S, et al. Management of imported cutaneous larva migrans: a case series and mini-review. Travel Med Infect Dis 2015;13:382-7. 
Copyright 2016 BMJ Publishing Group. All rights reserved. For permission to reuse any of this content visit http://group.bmj.com/group/rights-licensing/permissions.

BMJ Case Report Fellows may re-use this article for personal use and teaching without any further permission.

Become a Fellow of BMJ Case Reports today and you can:

- Submit as many cases as you like

- Enjoy fast sympathetic peer review and rapid publication of accepted articles

- Access all the published articles

- Re-use any of the published material for personal use and teaching without further permission

For information on Institutional Fellowships contact consortiasales@bmjgroup.com

Visit casereports.bmj.com for more articles like this and to become a Fellow 